\title{
Con Amore: Henry Johnstone, Jr.'s Philosophy of Argumentation
}

\section{James Crosswhite University of Oregon}

\begin{abstract}
Henry Johnstone's philosophical development was guided by a persistent need to reform the concept of validity-either by reinterpreting it or by finding a substitute for it. This project lead Johnstone into interesting confrontations with the concept of rhetoric and especially with the work of Chaim Perelman and Olbrechts-Tyteca. The project culminated in a failed attempt to develop a formal ethics of rhetoric and argumentation, but this attempt was itself not consistent with some of Johnstone's other characterizations of an ethics of argumentation. A virtue ethics would be truer to the Johnstonian philosophical project than a formal ethics of argument.
\end{abstract}

Résumé: C'est le désir persistant de Henry Johnstone d'améliorer le concept de validité - soit en le réinterpretant ou soit en le rempliant -qui guide son évolution philosophique. Ce projet le mène à affronter le concept de rhétorique et surtout l'oeuvre de Chaïm Perelman et Olbrechts-Tyteca. Ce projet se termine dans une tentative échouée de concevoir une éthique formelle de rhétorique et d'argumentation. En plus, cette tentative est-elle même incohérente avec quelques unes de ses autres caractèrisations d'une éthique d'argumentation. En fin de compte, une éthique de la rhétorique et de l'argumentation fondée sur une éthique de la vertu s'appliquerait plutôt au projet philosophique de Johnstone qu'une éthique formelle de l'argumentation.

Keywords: Henry W. Johnstone Jr, argumentation, rationality, validity, rhetoric, Perelman, ethics of rhetoric, virtue ethics.

In the epilogue to his 1978 Validity and Rhetoric in Philosophical Argument, Henry Johnstone reconstructed over a quarter century of his own philosophical development. In this paper, I revise this reconstruction, reconstructing Johnstone's thinking again, amplifying Johnstone in some places, taking issue with him in others. Specifically, (1) I show that Johnstone's philosophical projects were more unified than he knew and that he was wrong when he wrote that his work on validity was inconsistent with his work on the self. (2) I explore in more detail than Johnstone did the connections and disconnections between his philosophy of argumentation and Perelman and Olbrechts-Tyteca's. (3) I attempt to show that although Johnstone's move to an ethics of rhetoric was a natural outcome of his philosophy of argumentation, his development of a formal ethics of rhetoric was in conflict with some of his most powerful insights, and I propose that an ethics of intellectual virtues would be more likely to advance a Johnstonian philosophical project. 


\section{Argumentum ad Hominem}

Henry Johnstone's road into rhetoric was taken decisively with his early article on argumentum ad hominem. This article marks a break with his earlier empiricism and sets up the problems with which he would concern himself in future years. In this paper, I am not so much concerned with Johnstone's original arguments as with the philosophical predicaments his conclusions get him into-and then the arguments he makes in order to get out of those predicaments. The ultimate question at issue regards the source of an argument's authority, the standard by which we know whether an argument is "valid" or not. In his "Philosophy and Argumentum ad Hominem" (1952), Johnstone concludes that there simply are no logical or empirical standards by which philosophical controversies can be resolved. His concern here is with the problem of the self-reference of philosophical utterances. If a philosopher says, "All knowledge is derived either from logic or from senseexperience," then we want to know how the speaker came by that knowledge because it seems to have been produced by neither logic nor sense-experience. However, the difficulty is an artifact of someone's actually uttering the sentence and not an intrinsic flaw of the proposition itself. It is the speaker who incurs the burden of explaining the relation of how the utterance can be consistent with what is uttered. This is a practical problem-to the extent that Johnstone even calls the speaker's obligation a "categorical imperative." This makes the argumentum ad hominem available to the speaker's philosophical critics. And the success of the argumentum ad hominem is a philosophical success in that it is in the end capable of refuting the proposition itself because "if one proponent can be refuted by argumentum ad hominem, all can" (p. 11). And so Johnstone recovers something a great deal like logical validity (universality of rational force, if not a priori or analytical truth).

This is an enormous step for a former empiricist and a proto-rhetorician, "No genuine argumentum ad rem is available for philosophical controversy" (p. 8); instead, all philosophical argumentation is essentially a matter of communication, essentially ad hominem. It is difficult not to hear something of Perelman and Olbrechts-Tyteca (1969) here. They describe their own "rapprochement" with rhetoric as lying in their recognition of the fact that "it is in terms of an audience that an argumentation develops" (p. 5). In both cases, there is a fundamental and perspective-altering shift from logical standards to communicative ones-to a view of reason as communicative. Perelman and Olbrechts-Tyteca take this as tantamount to a rapprochement with rhetoric; Johnstone finds his own path to rhetoric by a different way, but it is worth considering here whether the article on the ad hominem did not set him on this path.

Another parallel with Perelman and Olbrechts-Tyteca is in Johnstone's notion of a pragmatic paradox and its being logically distinct from a contradictory proposition. This resembles fairly closely Perelman and Olbrechts-Tyteca's distinction between incompatibility and contradiction. Among the incompatibilities they analyze 
is what they call "autophagia," some of which result from "self-inclusion." They give the following examples:

The positivists, who insist that every proposition is either analytical or empirical, may be asked whether what they have just said is an analytical proposition or an empirical one. The philosopher who insists that every judgment is a judgment of reality or of value, may be asked what is the status of his assertion. The person who argues against the validity of any nondemonstrative reasoning may be asked what is the value of his own argumentation.

(p. 204)

Perelman and Olbrechts-Tyteca take the difference between a theory of argumentation that focuses on incompatibilities (which are practical) and contradictions (which are logical) to be the difference between a rhetorical theory and a logical theory. Again, very early on Johnstone seems to be making some of the same philosophical moves as Perelman and Olbrechts-Tyteca, and yet he does not at all take himself to be developing anything like a rhetoric of argumentation.

\section{Rhetoric and Validity}

Johnstone did not gravitate toward rhetoric without experiencing a significant counter pull from his own ideas about the difference between philosophy and rhetoric. In "Persuasion and Validity in Philosophy" (1965), he develops the contrast between philosophy and rhetoric as a contrast between bilaterality and unilaterality. Johnstone thinks of rhetoric as the employment of persuasive techniques for the purpose of gaining an audience's assent. In this kind of communication, a speaker may conceal these techniques so that the causes of an audience's assent are hidden from it. In philosophical communication, this is not possible: "A conclusion has no philosophical use if it is not reached freely" (p. 19). The philosopher must make his or her techniques fully known to the audience so that the audience can evaluate them as reasons and judge for itself the strength of the reasoning. Johnstone will abandon this particular conception of rhetoric for others, but this essay shows that he will not be pulled into rhetoric's orbit easily.

Two other connected ideas come to light in this article-Johnstone's difficulty with Perelman and Olbrechts-Tyteca's notion of a universal audience and the related idea of the intractability of philosophical controversy. These ideas are connected in their insistence on an openness to otherness in philosophical argumentation, a regard for deep and possibly decisive differences in philosophical orientations. Once one has, in the best New Rhetoric fashion, constituted the universal audience, members of that audience that will not be convinced by one's argumentation can only finally be labeled recalcitrant and thus disqualified. In Johnstone's view, this is not the way genuine philosophical argumentation works; in fact, it is tantamount to convincing only a model one has invented. A related objection is that if philosophical controversy is intractable - and Johnstone believes that it is - then the audience that will be convinced by one's arguments will always be a limited 
and not a universal one. I believe that the idea of a universal audience can be reconstructed so as to escape these objections (Crosswhite 1996), but the objections themselves reveal an essential element in Johnstone's thought-an acknowledgement that differences in philosophical perspectives are sometimes located beyond the reach of simple argumentative reason and so require a special kind of critical treatment.

This acknowledgment led Johnstone through several attempts to reconstruct the concept of validity in argumentation. He often thought of the main challenge to the concept of validity as "the consistency problem." What if an "opponent" refuses to acknowledge an inconsistency one points out between his presuppositions and his statement? To what does one then appeal? Inconsistencies are not facts or things-there is no argumentum ad rem. In "Argumentation and Inconsistency" (1961), Johnstone finds that in the philosophy of logic, the functionalist and the realist fail to come to agreement precisely because they have different criteria for making judgments about consistency and inconsistency. In "Philosophy and Argumentum ad Hominem' Revisited" (1970), this develops into a concern about philosophical "purblindness," in which our deep philosophical commitments make this level of our interlocutor's reasoning opaque to us-make us incapable of understanding consistency and inconsistency the way our interlocutor does. Johnstone's way of addressing this worry generates far-reaching revisions of his concepts of rhetoric and validity in a way that links them to his evolving concept of the self.

In "Rationality and Rhetoric in Philosophy" (1973) Johnstone makes a decisive revision of his concept of validity. He had never insisted on a merely formal notion of validity; he knew that philosophical arguments did not resemble proofs. However, he did seem to believe that validity was a property of arguments. His notion of the validity of the ad hominem rested on the possibility of rationally forcing an interlocutor to acknowledge inconsistencies. However, in this essay Johnstone executes a radical revision of the concept of validity, according to which philosophical argumentation proceeds "only because philosophers have a deep and pervasive concern with validity.... No activity beside philosophy has ever shown such a concern. [T] he entire rationality of the philosophical enterprise reduces to its concern ... to examine arguments" (p. 80). Validity itself, he said later, functions as a "regulative ideal" $(1978$, p. 135). Rationality is from this perspective much less a cognitive and much more a practical matter. The results of this will come full force in Johnstone's eventual embracing of rhetoric.

\section{Consistency and Inconsistency}

An essential motivation for these changes is Johnstone's growing tolerance of inconsistency, or the "strife of systems." Johnstone had always had a deep respect for otherness and for controversy. However, it was not clear that this would develop into a position from which he would argue that inconsistency was relative 
to systems of criteria for inconsistency, but here we have it. Johnstone later interprets this move not as a resolution but as a "repudiation" of the consistency problem $(1978$, p. 136). I do not believe that he is reading himself correctly, though. The transformation of the concept of validity is better understood as a reinterpretation of the consistency problem, situating it even more deeply at the practical level. It is true that consistency is no longer the defining mark of a good argument, of validity, and relative inconsistency does not make an argument wholly without merits. Given this perspective, an interlocutor is not either "forced" or "not forced" to acknowledge an inconsistency. Instead, from this perspective, there is admissible disagreement on inconsistency - the claim about inconsistency is supported by argumentation which itself may be successful to a degree. This is not a repudiation of the consistency problem "altogether" (1978, p. 136). There is still a "consistency problem" in that there is neither an argumentum ad rem that will resolve a conflict about inconsistency nor any assurance that one's interlocutor will be persuaded to acknowledge an inconsistency. This remains a problem, but it has become a practical problem. One might well convince one's interlocutor. Philosophical interlocutors are concerned with the validity of arguments, and this concern regulates and structures the argumentation; it generates a practice.

Johnstone says that he also treated the consistency problem in another way that does not repudiate it $(1978$, p. 137). Philosophical reasoning demands that one understand one's "opponent's" view as he or she does-as a whole, seen from within, from which point one's own position appears to be inconsistent. But occupying two contradictory and mutually exclusive positions at once is itself a kind of inconsistency. This event generates the Johnstonian self (1970)-which is conceptualized as that which can bear the "burden" of contradictory views. Philosophical reflection thus produces the self.

Johnstone believes that these two approaches are themselves inconsistent in that the idea of the self solves the consistency problem and the regulative ideal approach repudiates it. However, adopting a view of reason as practical-and Johnstone has by this point pretty much done so without explicitly saying sounifies these two approaches. The regulative ideal regulates philosophical practice-it is an ideal that informs the intellectual virtue of concern-for-validity. At the same time, this regulative ideal provides an ideal for the self-intellectual integrity. These two approaches are different adumbrations of the same approach-a turn to a vision of the "practical" existence of a self one of whose ways of being itself is argumentation. Argumentation for which validity is a regulative ideal remains argumentation in which interlocutors must grasp one another's arguments from one another's perspectives and still go on with the argumentation with the aim of convincing one another and themselves. And the Johnstonian self, which can tolerate this being in a state of conflict with itself, a state of seeing from more than one perspective, is precisely the kind of self which is able to engage in such argumentation. 


\section{Rhetoric as Evocation and Wedge}

This recasting of the idea of validity sets the stage for a new concept of rhetoric. In "Rhetoric and Communication in Philosophy" (1970b), Johnstone argues that in this new framework philosophical argumentation has a special evocative function, and although he finds a similar view in Wittgenstein and throughout the tradition, he gives this idea a strongly Heideggerian cast: philosophical argumentation "recalls to us our authentic language or mode of being" (p.138). The problem in this view is that human beings have somehow been drawn away from an understanding of what they really are, what they really desire, what they really believe. They are not only in a state of confusion; their very desire for truth is breaking down. Johnstone calls this loss of hope and confidence a loss of morale. Philosophical argumentation, in its rhetorical work, attempts to evoke a true experience of one's own being, an authentic self-understanding, an honest awareness of one's own desire. Unless one desires this, unless one is able to acknowledge that one is to some degree out of touch with oneself, philosophical argumentation that might engage inconsistent perspectives is simply impossible. Johnstone sees this move to argumentation as evocation as a continuation of the line of reasoning that "repudiates" the consistency problem. However, he also acknowledges that this line converges with the other line that develops the idea of a self-for evocation is all about self-understanding and the burden of self-knowledge.

Yet, without validity or any other philosophical authority, what assures us that the experience evoked in argumentation, and the morale we gain at the high price of an awareness of the contradictions we are, are true and genuine? Johnstone addresses this question in "Rationality and Rhetoric in Philosophy" (1973). In this essay, the evolution from a theory of validity to an ethics of argumentation is completed. Or perhaps it is more accurate to say that the ethical terms Johnstone articulates in this essay are interpretations of validity, parts of an ethical theory of reason. In this essay, argumentative reason is saved from irrationality by a "selfperpetuating rhetoric that criticizes con amore" (pp.84-85). Criticizing argumentation con amore is to criticize on behalf of the one whose arguments one is criticizing. Here Johnstone is very close to Nietzsche and Stanley Cavell (Cavell 1990) in their conception of philosophical friendship-i.e., the philosopher who criticizes con amore is the enemy of my present attainments and the friend of my next self. The idea of a self-perpetuating rhetoric is of argumentation that "must always establish the conditions for [its] own continuation" (Johnstone 1973, p.84). This acknowledges that no argument is final, that validity is a "regulative ideal" (1978, p.135), that there is in the con amore principle a perfectionist vision of endless self-revision. This is a long way from anything like a traditional judgment of validity.

This new concept of rhetoric's evocative function in argumentation is related to another important development in Johnstone's changing conception of rhetoric. In "The Philosophical Basis of Rhetoric" (1978), Johnstone first develops his 
famous concept of "rhetoric as a wedge," which informs the thesis that "Rhetoric is the evocation and maintenance of the consciousness required for communication" (p. 129). People can always refuse to accept statements because facts never speak for themselves. In this insistence that consciousness is essentially "negative," one gets a clear view of the usually well-camouflaged Hegelian strain in Johnstone's thought. Johnstone insists that there is a potential "distance" between any person and what is communicated to him or her (p. 130). There is judgmental mobility in this space. This distance is not always there-often we just accept what we hear or see without reflection. Johnstone's "consciousness" (by which he means "reflective consciousness") is an "interruption" of the unity of the transaction between subject and object, an interruption in which the possibility of accepting or rejecting arises. Thus, there also arises a "contradiction" between the data and the subject-a disagreement of sorts. Rhetoric is now thought of as the art of creating this interruption and amplifying this contradiction between a person and the data of his or her immediate experience. This event must arise within the individual who is receiving communication, and cannot simply be forced from without--there would be no true wedge in that case, no consciousness, and so the idea of rhetoric as evoking this event is pertinent-although it may sometimes feel like an impertinence. Since this rhetorically-induced reflection makes one conscious of some things but not all things, it is always a matter of controversy. However, this conception of rhetoric also distinguishes it from coercion, hypnosis, brainwashing, etc. Rhetoric arises in conditions of "contradiction," of uncertainty. It generates an awareness of a lack - of knowledge, a lack of certainty, a lack of self-coincidence, and, in a way, of "morale." However, it is also a recovery of morale, of the conviction that there is a way to reason in conditions of uncertainty, even though this will require something more than logic - it will require the humility involved in perpetuating uncertainty and the arguments that address it, and it will require that criticism (which has no natural limits) be tempered con amore.

This idea of rhetoric as a wedge is taken up by Caroll C. Arnold in an issue of Philosophy and Rhetoric that records a special panel at a meeting of the American branch of the International Society for the History of Rhetoric. In many ways, I am in full concord with Arnold's further development of Johnstone's concept, but I would like to raise some objections to one part of Arnold's project—objections to which Johnstone himself apparently conceded. Arnold, following Molly Wertheimer, cites Dewey's Human Nature and Conduct :

The occasion of deliberation is an excess of preferences, not natural apathy or an absence of likings. We want things that are incompatible with one another; therefore we have to make a choice of what we really want .... Choice is ... the emergence of a unified preference out of competing preferences. (Arnold 1987, p. 120)

Wertheimer's amendment to this passage is to speak of rhetoric as revealing "an excess of possible ways to be." Arnold supports this change as a friendly amend- 
ment that is in the spirit of Johnstone's project. I agree completely with Arnold here, and the Heideggerian ring of "possible ways to be" also folds in nicely with Johnstone's conception of the self as this same kind of excess of incompatible ways to be.

However, I want to take issue with the way Arnold seems to me to avoid the "incompatible" that shows up in Dewey's statement here. Here is Arnold:

I want to enter a mild demurrer to a term Johnstone used in his early explanations of rhetoric-as-wedge. Johnstone wrote of "contradiction" as the phenomenon that evokes the self and self-rhetoric. ... I prefer to say that awareness of similarities and differences between an initiating rhetor and myself is what evokes the self-consciousness that allows creative, evaluative self-rhetoric. (p. I2I)

I believe that there is a problem with this attempt at creating a kinder, gentler Johnstone concerned with "awareness of differences" instead of contradictions and with "invitations" instead of arguments. I am going to insist instead on a more Heraclitean Johnstone, one for whom strife is a kind of justice, for whom the fairest concord might come from discord, and for whom the best harmony remains in important ways hidden from us. I believe that even in Arnold's comments on the wedge there is an implicit acknowledgment that something more than a simple awareness of differences is at stake. The Dewey passage speaks explicitly of preferences that are incompatible with one another and not just different from one another.

A simple awareness of one's differences from others need not generate the Johnstonian self nor lead to reflection or reasoning of any kind. Many of the ways we are different from others are not due to deep incompatibilities between our ways of life. And most of the deep differences we do become aware of we simply accept or ignore. Only in some cases do we feel challenged by the views or lives of other people; only in some cases do we feel that a claim is being made on us, that we are facing an incompatibility that must be resolved. This begins to occur when we start to embrace, to some degree, a way of understanding that is incompatible with our own. Interestingly, for Hans-Georg Gadamer (1989), to understand means, in part, to accept the other's view, and this is the beginning of the trouble that Johnstone calls "the self." What Gadamer means by "understanding" is nothing trivial. The phenomenon of choices among ways of being arises only if I am in some sense claimed, only if I experience a conflict between two ways of being-my own and another that is making a claim on me. Not all experiences of difference are like this-no matter how sensitive to similarities and differences I might be. For Johnstone, the event of rhetoric is the event of the self-experiencing an incompatibility, a conflict, articulated as a "contradiction," that calls for reason and choice. Neither the dictum that supports my continuing with my perspective nor the dictum that supports my changing my perspective has immediate force. Instead I am (come to be) in the wedged-open space of the contradiction. "Homer was wrong in saying, 'Would that strife might perish from amongst gods 
and men.' For if that were to occur, then all things would cease to exist." In a similar way, Arnold was wrong in saying "Would that contradiction might pass from Johnstone's theory of rhetoric as wedge." For if that were to happen, reason and the self would cease to exist.

Johnstone responds to what others have said about the rhetoric-as-wedge idea not by replying directly to their comments but by trying to develop the idea itself in a new way:

The wedge of rhetoric separates the person to whom a thesis is being addressed from that thesis itself; it puts him over against the thesis causing him to attend to it as an explicit idea that he might previously have been unaware of because it figured only implicitly in his experience. My view emphasizes attention; I regard rhetoric as the art of getting attention. (1987, p. 130)

Importantly, Johnstone insists that the attention he is attempting to describe is not simply psychological. Neither is it only an attention to theses: "Philosophy, or at least metaphysics, is par excellence a matter of attention and inattention. What a metaphysician attends to is the world as characterized by whatever feature or features he regards as fundamental" (p. 131). So, Johnstone notes, Parmenides attends to the changeless, Plato to form, Aristotle to purpose, and so on. In giving attention, each also withdraws it-Parmenides from change, Plato from action and matter, Aristotle from chance (p. 131).

There are several remarkable facts about this development. First, Johnstone means by "attention" something fairly far-reaching. The closest idea to it I can think of is Heidegger's idea of truth. For Heidegger, truth is a coming out of hiddenness into unconcealment, an "unveiling." Before the event of truth, which is a way of being for human beings, things lie hidden. As Johnstone says, "Objects and theses, when not attended to, lapse into an unnoticed background" (p. 130). Further, Heideggerian truth has a strong connection to the event of being - and Johnstone finds a similarly strong connection between "attention" and metaphysics. "Attention" allows being to be experienced as change or form or as having purpose. To take this even further, just as for Heidegger all truth is an event of both concealment and unconcealment, so for Johnstone "attention" brings some things to light and lets others fall into an "unnoticed background."

Second, this ontological idea of "attention" now carries the primary weight of the rhetoric-as-wedge idea to the extent that rhetoric just is the art of getting attention-a letting things come into presence. It is useful to try to think this definition together with the earlier definition according to which "Rhetoric is the evocation and maintenance of the consciousness required for communication" (1978, p. 129). Here, the art of evoking consciousness is now equivalent to the art of evoking what Johnstone is calling "attention." And here, too, as nearly always in Johnstone, consciousness means something like specifically human consciousness, a consciousness capable of philosophy, capable of what Johnstone calls "contradiction." For immediately after his exposition of the idea of attention, he 
turns to one of his persisting themes-the idea of the "strife of systems," in this case, the problem of how two fundamentally incompatible patterns of attention can be brought into communication, can enter into an argument with one another.

Johnstone's solution is again, and consistently, the argumentum ad hominem. The ad hominem is the form that the wedge must take in order to expand attention. Johnstone's view is that genuine reasoning, the kind in which one is taking a risk, entertaining the possibility of changing one's mind, does not take place simply in opposing one system of attention to another. The idea seems to be that each system of attention has a kind of translation manual for interpreting the terms of the opposing system into its own. For example, Johnstone says that Aristotle conceptualizes chance as a kind of purpose-gone-wrong.

Instead, "the art of wedge-driving [requires] . . . a kind of intellectual auscultation to discriminate the hard places in the position of another-places which will not admit the point of a wedge-from the soft places that are wedgeable" (1987, p. 132). For example, a behaviorist may claim that all choices are a result of operant conditioning, but may also admit that the choices made in designing experiments seem to be led in a special way by reasons. Johnstone believes that this may be a wedgeable site because there is something in the experimental behaviorist's experience, an implicit kind of knowledge, that allows this attention to be evoked, allows amplification.

Readers of The New Rhetoric might wonder why Johnstone did not use Perelman and Olbrechts-Tyteca's idea of "presence" here. The rhetorical act of "endowing presence" is a bringing to attention. It has a psychological concomitant but it can also become "an essential element in argumentation" (p. 117). Presence is always selective, and because it is selective, it leads to a relative "overestimation" of importance. In addition, "it cannot avoid being open to accusations of incompleteness and hence of partiality and tendentiousness" (p. 119). Perelman and OlbrechtsTyteca even develop the perfectionist character of this process of evoking presence and criticizing the partiality of the evocation, and this aligns precisely with Johnstone's ideal of a self-perpetuating rhetoric:

[Asserting] that the totality of informational elements must be presented, giving to each element the emphasis it deserves, would imply the existence of a criterion for determining those relevant elements and would imply also that the totality defined in this way can be exhausted. We think this is an illusion and that passage from the subjective to the objective can be accomplished only by successive enlargements, none of which can be regarded as final. The person who effects a new enlargement will necessarily emphasize that the previous statements had involved a choice of data, and he will probably be able to show quite easily that this was indeed the case. (pp. 119120)

I quote this passage at length both because of the clear self-perpetuating process of this art of evocation of presence and because the "successive enlargements" seem to depend upon something like a space opening up, a wedge being driven 
between someone who experiences presence and the presence he or she experiences, so that something new might come to presence in that space cleared by the wedge.

\section{Johnstone, Perelman and the Ethics of Rhetoric}

This question about Johnstone and Perelman and Olbrechts-Tyteca takes me directly to an issue that can be postponed no longer: the nature of Johnstone's encounter with Perelman and with the new rhetoric that he and Olbrechts-Tyteca developed. If Johnstone was gradually developing a notion of philosophical argumentation that depended on rhetoric and a concept of rhetoric that was fit for philosophy to make use of, why did he not make use of The New Rhetoric's elaboration of a parallel development? I know of at least two different ways Johnstone characterized the relation between his thought and Perelman's. In the "Epilogue" to Validity and Rhetoric in Philosophical Argument, he says that his reviews of Perelman's work never did occasion changes in his own ideas. Instead: "They serve as a bass continuo to the melodies [Johnstone's own] that are weaving themselves in the upper registers. For here is a constant story I have always been criticizing, even though my criticisms have taken many and sometimes inconsistent [!] forms" (p. 139). And then in a June 29, 1999 e-mail to my colleague David Frank: "I don't think I ever addressed Perelman in his own terms, nor he me. We were friends, but in philosophy passed each other like ships in the night."

Johnstone missed several opportunities for a productive engagement with The New Rhetoric. His central philosophical position that all philosophical argumentation is ad hominem could certainly be explored in connection with the new rhetorical claim that all argumentation develops in relation to an audience. However, Johnstone never could fathom how the concept of audience functioned for Perelman and Olbrechts-Tyteca. His concept of the pragmatic paradox into which inconsistent philosophical speakers fall could also easily be explored with or compared with the new rhetorical idea of incompatibilities as opposed to contradictions. And then in his search for a non-psychological way of conceptualizing rhetoric as an art of getting a special kind of attention, Johnstone ignored The New Rhetoric's very useful development of the idea of rhetorical presence.

However, I want to comment on only one of Johnstone's objections to Perelman and Olbrechts-Tyteca's theory of argumentation, and then I want to conclude with an examination of a convergence of their work in essays published in 1981, for this convergence expresses a common and quite significant philosophical result of their separate careers. Johnstone had many objections to The New Rhetoric's idea of a universal audience, and I believe that I have dealt with most of them, at least implicitly, elsewhere (Crosswhite 1996). However, one of these objections seems to me to hold some continuing force, beyond all responses. This is the objection that to say that one convinces a "model" or a "construction" of one's own seems to obscure the way in which one's interlocutor constantly exceeds 


\section{James Crosswhite}

one's constructions or models. One's philosophical interlocutor is not an idea or a model. Johnstone's deep regard for the otherness of interlocutors finally undermined his own earlier notions of validity and universality. He could no longer find a universal position from which to judge consistency and inconsistency. Instead, he developed a concept of the self as a locus of inconsistency, an entity that could bear contradictions, that could see the reason in incompatible positions, that could acknowledge the other's radical difference from itself (1970). It is true that Perelman was concerned with the very possibility of argumentation as an alternative to violence and dogmatism. He wanted to show how it could and had succeeded. He was not concerned with aporia or radical difference or situations in which argumentation failed to reconcile parties in conflict. However, Johnstone was interested in such matters, and as a consequence became interested in a deeper rhetoric of evocation that might lead to new self-understandings and so new situations in which argumentation might proceed. The question for Johnstone was how to engage in such a rhetoric rightly when the measures of validity and universality were unavailable. His essential charge against the idea of the universal audience was that it settled matters too easily, that it erased the otherness of the philosophical interlocutor.

Henry Johnstone and Chaïm Perelman finally converge and diverge on an issue that is ultimately among the most important for each of their philosophical projects. In "The Rhetorical Point of View in Ethics: A Program" (1981), Perelman elaborates in his own language of "dissociation" a theory of rhetoric as both evocation and wedge:

[T] he role of rhetoric has been to strengthen the cause which, at first glance, appears the weakest. Its role is to point out where the real interest to be sought lies; it is actually to oppose reality to appearance. He who identifies what appears at first glance to be good or evil, namely, pleasure or suffering, with true good or evil, should simply follow his instincts. But he who opposes them needs rhetoric to dissociate reality from appearance. How could one resist one's passions without rhetoric? . . . Discourses are needed to resist what is natural and spontaneous, to evoke and make present what does not impose itself at first glance. (p. 319)

Any reader of Johnstone will find this passage nearly astonishing in its detailed parallels with Johnstonian ideas and arguments. One finds what Johnstone would call an unconscious self that knows no difference between its desires and itself. And yet a rhetorical wedge enters and divides it from its desires by evoking an awareness of something else that it also in some sense desires. A conscious self that desires incompatible things and must make a reasonable choice has emerged. Where Johnstone would say "evoke," Perelman says "point out," "evoke," and "make present." Where Johnstone would say "drive a wedge," Perelman says "dissociate." Where Johnstone would say "unconscious," Perelman says "follow[s] his instincts." 
However, if Johnstone and Perelman converge here in a vision of the unity or interdependence of ethics and rhetoric, Johnstone pushes more relentlessly in his quest for a way of knowing whether one has evoked rightly, whether and how rhetorically inflected philosophical argumentation can be justified. All of Johnstone's work leads him to this point, and in "Toward an Ethics of Rhetoric" (1981) he reformulates ideas he has expressed along the way. I want to conclude this exploration of Johnstone's philosophy of argumentation by explaining and reconstructing this ethics of rhetoric-for I believe that Johnstone's thinking is moving in a logically ineluctable way toward a view of a virtue ethics of thetoric in which virtues take something like the place played by more logically and epistemologically cast notions like validity and universality. In this move, which bears some resemblance to Emmanuel Levinas's project of finding the ethical to be prior to and more fundamental than the ontological, Johnstonian thinking also finds a way to continue to express respect for the inassimilable difference of the philosophical interlocutor.

In "Toward an Ethics of Rhetoric" (1981), Johnstone reasserts his two principles of practicing rhetoric con amore and as a continuing, "self-perpetuating" activity that leaves issues open to further argumentation. These are highly significant principles for Johnstone in that they both constrain and authorize the evocative and critical actions that can be brought to bear on an interlocutor who will not acknowledge that he or she has been reasoning in an inconsistent way. However in this 1981 article, under the influence of ethical-theoretical demands, Johnstone makes, I believe, a philosophical mistake, and misinterprets his own earlier work. In "Rationality and Rhetoric in Philosophy," he characterizes these principles in an informal way:

[I]t is not on the basis of logical power that we make the distinction between sophistical and responsible criticisms of philosophical arguments .... The basis on which we do make the distinction, I think, is the interest of the critic in maintaining the philosophical enterprise. In criticizing, he is implicitly appealing to his interlocutor to do better, to produce a better argument. $\mathrm{He}$ criticizes con amore.... Whether a critic is criticizing con amore or not cannot be determined from his criticisms as such .... It is revealed only in the way he goes about his work-lovingly or viciously. There is nothing arcane about our knowledge of this intention, provided that we look for the knowledge in the right place. (p. 84)

This informal characterization has some interesting features. The con amore is focused on the interlocutor him or herself. The envisioned outcome of reasoning con amore is that the interlocutor will offer yet better arguments. And whether someone is criticizing con amore or not is revealed only in "the way he goes about his work."

The principle of self-perpetuating rhetoric also receives informal characterization in the earlier article: 
The arguments and criticisms of the philosopher must always establish the conditions for their own continuation.... The rhetoric that demolishes the arguments of the past does so in such a way as to show respect for these arguments; it demolishes them con amore.... It is this self-perpetuating feature of the rhetoric that is the rationality of philosophy which distinguishes it from rhetoric occurring in other domains. A point is never reached at which the rhetoric of the critique of arguments cannot be reinjected into the argumentative situation. (pp. 84-5)

Contrast these informal characterizations to the formal account offered in "Toward an Ethics of Rhetoric" (1981). Just before this passage, Johnstone has reviewed his attempt to characterize rationality by the concepts of rhetoric con amore and of a self-perpetuating rhetoric. Then he asks for something more:

Since I reject any teleological ethics of rhetoric, and I know no alternative to teleological and deontological, I must opt for a deontological ethics of rhetoric. This means that I must have some formula corresponding to the Kantian categorical imperative by which to determine whether an act is right or not. I have already suggested such a formula, which I will now express by saying, "So act in each instance as to encourage, rather than suppress, the capacity to persuade and to be persuaded, whether the capacity in question is yours or another's." Let us call this formula the basic imperative. (pp. 309-10)

This is a radical shift from the earlier position. The specific interlocutor is no longer the focus here; instead, his or her capacity to persuade and be persuaded is. The person is thus treated as a means to enhancing this capacity-regardless of whether he or she wants to enhance this capacity in this instance, or rather wants the pursuit of this goal constrained or balanced by some other goal or principle. Second, whether someone is reasoning in an ethical way is no longer known by having to watch the way he or she goes about arguing with an interlocutor. Instead, one knows only by knowing whether the arguer's actions conform to a rule. But not only is amore finally codified and our poor interlocutor narrowly essentialized, but "the basic principle" begs the question it is designed to answer. The Johnstonian problem is that we do not know when or how to correctly persuade someone to acknowledge inconsistencies because our own arguments can no longer be measured by traditional standards of validity or universality. Johnstone proposes that in our attempts to persuade we act in each instance so as to encourage the capacity to persuade and be persuaded, our own capacity and that of others. However, surely we are not to encourage the capacity to be wrongly persuaded but only the capacity to be rightly persuaded. And surely we are to encourage the capacity to persuade rightly and not to persuade wrongly. However, if we are to look for a measure of what is rightly persuasive and what is not, we will find that validity and universality are of no use and that we must look to see whether the rhetoric that has been used encourages the capacity to persuade and to be persuaded - and then we will be right back where we started.

There is a way out of this, and I believe that it is a way more consistent with Johnstone's own philosophical development than his later Kantian formulations of 
an ethics of rhetoric are. Teleological and deontological ethics are not the only ethics there are. A virtue ethics is also available to us. When one acts from virtue one judges and chooses to do the right thing in the particular instance without the simple application of rules and metarules. Virtues are developed in the context of one's communities, one's education, one's different roles, from habit and from being taught. Virtues are best understood by watching virtuous people in action. Rules of action are mostly derived and hypothesized from observations of virtuous action. Just as exemplary experiments are often surer guides to an understanding of science than abstract characterizations of scientific method, so exemplary actions are often surer guides to understanding ethical action than formal ethical rules. This is especially the case when rules or hypotheses or methodologies come into conflict-and Johnstone's philosophy of argumentation is directed precisely at cases of philosophical controversy.

I would like to end with what can remain here only a hypothesis-that an account of the ways in which intellectual virtues constitute the rationality of rhetoric and argumentation will further Johnstone's project more than a formal account of the ethics of rhetoric will. Reasoning con amore sounds much more like the exercise of an intellectual virtue than it does like the application of a rule. Developing a Johnstonian account of the ways intellectual virtues authorize argumentation could provide a whole new level of meaning to that challenging phrase, "informal logic."

\section{References}

Note: A number of Johnstone's articles are conveniently collected in his book, Validity and Rhetoric in Philosophical Argument. Although I identify the articles by their original dates of publication, I have used the pagination in this book to document citations from these articles. I have also included separate entries for the articles so that the original sources may be easily discovered.

Arnold, Carroll C. (1987). "Johnstone's 'Wedge' and Theory of Rhetoric." Philosophy and Rhetoric: 20, 118-128.

Cavell, Stanley. (1990). Conditions Handsome and Unhandsome. Chicago: University of Chicago Press.

Crosswhite, James. (1996). The Rhetoric of Reason: Writing and the Attractions of Argument. Madison: University of Wisconsin Press.

Gadamer, Hans-Georg. (1989). Truth and Method. Second, revised edition. Translation revised by Joel Weinsheimer and Donald G. Marshall. New York: Continuum. Original work published in 1960.

Johnstone, Henry. (1961). "Argumentation and Inconsistency." Revue Internationale de Philosophie 15, 353-365. Reprinted in Validity. 
Johnstone, Henry. (1965). "Persuasion and Validity in Philosophy." Chapter 9 of Philosophy, Rhetoric, and Argumentation, Henry Johnstone and Maurice Natanson (eds.). University Park, PA: Pennsylvania State University Press. Reprinted in Validity.

Johnstone, Henry. (1952). "Philosophy and Argumentum ad Hominem." The Journal of Philosophy 49, 489-498. Reprinted in Validity.

Johnstone, Henry. (1970) "'Philosophy and Argumentum ad Hominem' Revisited." Revue Internationale de Philosophie 24, 107-116. Reprinted in Validity.

Johnstone, Henry. (1970). The Problem of the Self. University Park, PA: Pennsylvania State University Press.

Johnstone, Henry. (1973). "Rationality and Rhetoric in Philosophy." The Quarterly Journalof Speech 59, 381-389. Reprinted in Validity.

Johnstone, Henry. (1987). "Response." Philosophy and Rhetoric 20, 129-134.

Johnstone, Henry. (1970b). "Rhetoric and Communication in Philosophy." In Perspectives in Education, Religion, and the Arts, Howard E. Kiefer and Milton K. Munitz (eds.), 351-364. Albany: State University of New York Press.

Johnstone, Henry. (1981). "Toward an Ethics of Rhetoric." Communication 6, 305-314.

Johnstone, Henry. (1978). Validity and Rhetoric in Philosophical Argument: An Outlook in Transition. University Park, PA: Dialogue Press of Man and World.

Perelman, Chaïm and Lucie Olbrechts-Tyteca. (1969). The New Rhetoric: A Treatise on Argumentation. Translated by John Wilkinson and Purcell Weaver. Notre Dame: University of Notre Dame Press, 1969. Original work published in 1958.

Perelman, Chaïm. (1981). "The Rhetorical Point of View in Ethics: A Program." Communication 6: 315-320.

James Crosswhite

Department of English, Unversity of Oregon Eugene, Oregon 97403-1286, U.S.A. jcross@oregon.uoregon.edu 